\title{
Keefektifan Pemantapan Kemampuan Guru SMK Dalam Menulis Proposal Penelitian Eksperimen
}

\author{
Albrian Fiky Prakoso ${ }^{1,}$ Novi Trisnawati ${ }^{2,}$ Yoyok Soesatyo ${ }^{3}$ Waspodo Tjipto Subroto ${ }^{4}$ Norida Canda Sakti ${ }^{5}$. \\ ${ }^{1}$ Universitas Negeri Surabaya \\ ${ }^{2}$ Universitas Negeri Surabaya \\ ${ }^{3}$ Universitas Negeri Surabaya \\ ${ }^{4}$ Universitas Negeri Surabaya \\ 5Universitas Negeri Surabaya
}

\section{ARTICLE INFO}

Article history:

Received: May 2019

Accepted: June 2019

Published: $1^{\text {st }}$ Juli 2019

Keywords:

Steadiness, Teacher, Experimental Research.

\section{ABSTRACT}

The teacher's lack of understanding in preparing experimental research proposal is one of the factors why teachers are reluctant to do research. On the other hand, teachers need mentoring program to increase their interest in conducting experimental research. The purpose of this PKM are (1) provide teacher's understanding of experimental research, (2) provide assistance in compiling an experimental research proposal framework, (3) provide assistance in preparing experimental research proposal. The subjects in this PKM are teachers of the IKIP Gedangan Vocational School and the IKIP Surabaya Vocational School. The object of this PKM is training in writing experimental research proposals. The PKM implementation method is divided into 2 activities, namely the provision of material on experimental research with varied lecture methods and the practice of writing experimental research proposals simulation and presentation methods. The results obtained were quite effective because there was an increase in understanding after participants received training. On the other hand, there were also participants who still did not fully understand how the stages of experimental research began from problems, selection of control classes and experimental classes to data analysis. The important implication is teachers in Indonesia need training in research field so their career paths increased and become more professional. In the future, the assistance is continued until experimental research reports because the participants are very enthusiastic and curious to analyze data in experimental research.

How to cite: Prakoso, A. F. (2019). Keefektifan Pemantapan Kemampuan Guru SMK dalam Menulis Proposal Penelitian Eksperimen . Jurnal Pemberdayaan Masyarakat Madani (JPMM), $3(1), \quad 59 \quad-82$. https://doi.org/10.21009/JPMM.003.1.5

* Corresponding Author. 


\section{PENDAHULUAN}

\section{A. Analisis Situasi}

Berdasarkan studi pendahuluan pada Sekolah Menengah Kejuruan (SMK) menunjukkan bahwa guru memiliki kesulitan dalam melakukan penelitian. Rata-rata pengetahuan guru hanya sebatas melakukan Penelitian Tindakan Kelas (PTK). Berbagai pelatihan PTK telah banyak diikuti oleh guru. Pendampingan pelatihan PTK juga telah banyak diikuti seperti pendampingan yang dilakukan oleh Soejoto, Fitrayati, Ghofur, Sholikhah, \& Prakoso (2017) dan Soesatyo et al. (2018), namun guru membutuhkan jenis penelitian pendidikan lain bisa dilakukan dengan mudah dan bersamaan dengan waktu mengajar guru.

Banyak guru tidak menyadari akan kewajibannya untuk meneliti. Sebagian besar dari mereka hanya fokus dengan mengajar.

Berbeda dengan guru yang dalam statusnya sebagai pegawai negeri. Mereka diwajibkan bukan hanya mengajar tetapi juga meneliti agar mereka bisa naik pangkat.

Berdasarkan Peraturan Menteri Negara Pendayagunaan Aparatur Negara dan Reformasi Birokrasi No. 16 Tahun 2009 mengatakan bahwa "untuk kenaikan jabatan/pangkat setingkat lebih tinggi dari Guru Pertama, pangkat Penata Muda, golongan ruang III/a sampai dengan Guru Utama, pangkat Pembina Utama, golongan ruang IV/e wajib melakukan kegiatan pengembangan keprofesian berkelanjutan yang meliputi sub unsur pengembangan diri, publikasi ilmiah, dan/atau karya inovatif".

Berdasarkan peraturan tersebut maka karya ilmiah yang dibuat oleh guru tidaklah harus berupa PTK, karena dalam peraturan tersebut hanya menyebutkan "publikasi ilmiah. Oleh sebab itu, kegiatan Pengabdian Kepada Masyarakat (PKM) ini memperkenalkan jenis penelitian eksperimen sebagai dasar guru melakukan publikasi ilmiah.

Persoalan prioritas mitra dalam dalam hal ini Guru SMK IKIP Gedangan dan SMK IKIP Surabaya lebih ditekankan pada kesulitan dalam melaksanakan pengembangan keprofesian berkelanjutan pada sub unsur publikasi ilmiah. Jika sebelum tahun 2013 pangkat guru secara otomatis, maka setelah tahun 2013, pangkat guru tidak akan naik jika mereka tidak melakukan publikasi ilmiah. Sedangkan bagi sekolah secara umum, penelitian yang telah dilakukan oleh guru sangat berguna bagi sekolah ketika mengajukan akeditasi. Sehingga guru perlu melakukan penelitian yang saah satunya adalah penelitian eksperimen.

Pada dasarnya penelitian yang wajib dilakukan oleh guru adalah PTK. Namun untuk memudahkan guru dalam memahami PTK adalah dengan cara melakukan penelitian eksperimen terlebih dahulu. Hal ini dikarenakan PTK adalah penelitian eksperimen yang dilakukan berulang-ulang (siklus) (Arikunto, Suhardjono, \& Supardi, 2010).

Dengan melakukan penelitian eksperimen guru secara tidak langsung telah melakukan PTK dalam 1 siklus. Perbedaan mendasarkan antara PTK dengan eksperimen 
yaitu guru tidak perlu melakukan perbaikan dari semua kekurangan dalam proses pembelajaran sedangkan PTK harus diperbaiki agar tercapai suatu target yang telah dibuat oleh peneliti.

Sebagai tambahan, dalam kegiatan pemantapan ini diasumsikan peserta telah memiliki pengetahuan tentang analisis butir soal seperti pelatihan yang telah dilakukan oleh (Kurniawan, Prakoso, Hakim, Dewi, \& Widayanti, 2017). Hal ini dilakukan agar peserta dapat dengan mudah memahami alur penelitian eksperimen.

Dalam penelitian eksperimen diperlukan suatu instrumen yang digunakan untuk melaksanakan pre-test dan post-test. Dengan dimilikinya pengetahuan tentang analisis butir soal tentunya akan memudahkan guru dalam membuat penelitin eksperimen.

Selain itu peserta juga diasumsikan telah membaca contoh artikel tentang penelitian eksperimen. Salah satu contoh penelitian eksperimen yang dimiliki oleh pemateri yaitu artikel peneltiian yang dilakukan oleh Pahlevi \& Prakoso (2014) karena contoh artikel telah diberikan pada observasi awal.

Beberapa eksperimen yang pernah dilakukan dan diterbitkan pada jurnal education+training antara lain penelitian milik Clark (2009). Dalam penelitiannya dia memperkenalkan perkuliahan yang secara khusus diciptakan berdasarkan wawasan tokoh terkemuka dalam ekonomi heterodoksi.

Lebih unik, West (1962) sudah sejak lama memperkenalkan drama yang diimprovi- sasi - penciptaan drama dari situasi tertentu, diperkenalkan sebagai eksperimen dengan objek yang menunjukkan para siswa sesuatu dari perkembangan terbaru di Teater. Bergeser dari drama, Pillay \& James (2013) mengeksplorasi permainan, sebagai pedagogi alternatif, untuk meningkatkan sistem pembelajaran.

Lebih dari sekedar bermain, Hietanen \& Ruismäki (2016) membimbing siswa untuk bereksperimen dengan gaya yang berbeda dalam bernyanyi dan bermain instrumen, untuk mencari berbagai kesempatan untuk bernyanyi dan bermain baik secara individu maupun sebagai kelompok, dan untuk merefleksikan kegiatan mereka

\section{B. Perumusan Masalah}

Perumusan masalah dalam penelitian ini adalah "bagaimana keefektifan pelatihan terhadap kemampuan guru dalam menyusun proposal penelitian eksperimen?"

\section{Tujuan}

Dengan diadakannya pelatihan penulisan proposal penelitian eksperimen ini diharapkan memberikan kemudahan bagi guru dalam melakukan penelitian pada umumnya dan penelitian eksperimen pada khususnya.

\section{Manfaat Pengabdian Kepada Masyarakat}

Untuk menambah motivasi guru juga dilakukan pendampingan hingga proposal yang disusun oleh guru menjadi mudah untuk terselesaikan dan sesuai dengan teori penelitian terutama penelitian eksperimen. Dengan pelatihan ini juga akan memberikan warna yang berbeda pada jenis penelitian 
yang telah dilakukan oleh guru seperti PTK, sehingga guru tidak merasa jenuh dengan penelitian yang mereka lakukan.

\section{KAJIAN TEORITIK}

\section{Sejarah Singkat Penelitian Eksperimen}

Ilmu-ilmu sosial, dimulai dengan psikologi, meminjam metode eksperimen dari ilmu alam. Psikologi tidak sepenuhnya menggunakan percobaan sampai setelah tahun 1990 (Neuman, 2017).

Wilhelm M. Wundt, seorang psikolog dan fisiologi Jerman, memperkenalkan metode eksperimental dalam psikologi. Selama akhir tahun 1800-an, Jerman adalah pusat pendidikan pascasarjana, dan ilmuan sosial datang dari seluruh dunia untuk belajar disana (Neuman, 2017).

Wundt mendirikan labolatorium untuk eksperimen dalam psikologi yang menjadi model untuk penelitian sosial. Pada tahun 1900, berbagai univeritas di Amerika Serikat dan di tempat lain membentuk labolatorium psikologi untuk melaksanakan penelitian eksperimental (Neuman, 2017).

Namun, William James, seorang filsuf dan psikolog terkemuka, tidak menggunakan atau menerapkan metode eksperimental. Percobaan menggantikan pendekatan yang lebih filosofis, introspektif, dan integratif dalam psikologi yang lebih dekat dengan pendekatan ilmu sosial interpretif (Neuman, 2017).

Dari tahun 1990 sampai 1950, peneliti sosial menguraikan metode eksperimental hingga metode ini berakar kuat dalam berbagai bidang. Daya tarik penelitian percobaan adalah pendekatan ilmiah yang objektif dan tidak memihak untuk mempelajari kehidupan mental dan sosial dalam suatu era ketika penelitian ilmiah tentang kehidupan sosial baru mendapatkan penerimaan publik yang luas. Empat tren mempercepat perluasan penelitian sosial eksperimental: munculnya behaviorisme, penyebaran kuantifikasi, perubahan pada peserta penelitian, dan aplikasi praktis metode ini (Neuman, 2017).

Pertama Behaviorisme, adalah suatu pendekatan dalam psikologi yang ditemukan oleh orang Amerika JB. Watson dan dikembangkan oleh B.F Skinner. Pendekatan ini menekankan penciptaan ukuran yang tepat dari perilaku yang dapat diamati atau manifestasi lahiriah dari kehidupan mental diri dan mendukung percobaan untuk melakukan uji hipotesis empiris yang ketat (Neuman, 2017).

Kedua Kuantifikasi, atau mengukur fenomena sosial dengan ngka, dikembangkan antara tahun 1900 dan 1950. Para peneliti mengkonseptualisasikan konstruk sosial sebagai ukuran yang dihitung dan menyingkirkan konstruk non-kuantitatif (misalnya semangat, kesadaran, keinginan) dari penelitian empiris. Contohnya adalah mengukur kemampuan mental dengan menggunakan tes IQ. Awalnya dikembangkan oleh Alfred Binet, soerang Prancis, para peneliti menerjemahkan tes tersebut ke dalam bahasa Inggris dan merevisinya. Hal itu segera memiliki kegunaan dan daya tarik 
secara luas sebagai cara untuk mewakili sesuatu yang subjektif seperti kemampuan mental seseorang dengan skor tunggal dan menjadi suatu cara yang objektif dan ilmiah untuk memeringkatkan manusia. Antara tahun 1921 dan 1936, lebih dari 5.000 artikel diterbitkan mengenai tes kecerdasan. Banyak teknik penskalaan dan indeks yang dikembangkan dalam periode ini, dan para peneliti sosial mulai menggunakan statistik terapan (Neuman, 2017).

Seiring dengan waktu, orang-orang yang digunakan sebagai peserta berubah. Laporan awal penelitian sosial menyebutkan nama-nama individu tertentu yang berpartisipasi dalam penelitian, dan sebagian besar adalah peneliti profesional. Laporan berikutnya memperlakukan peserta secara anonim dan hanya melaporkan hasil tindakan mereka. Seiring waktu, terjadi pergeseran untuk menggunakan mahasiswa atau anak sekolah sebagai peserta penelitian. Hubungan antara seorang peneliti dan orang-orang yang dipelajari menjadi semakin jauh. Jarak tersebut mencerminkan tren bagi para peneliti eksperimen untuk lebih terpisah, terpencil, dan objektif dari orang-orang yang diteliti. Para peneliti melihat berkurangnya keterlibatan emosional dengan peserta penelitian dalam studi mereka karena semakin netral atau bebas nilai dan benar-benar "ilmiah" dalam pengertian positivis (Neuman, 2017).

Sewaktu peneliti menyadari aplikasi praktis dari percobaan, bisnis, pemerintah, fasilitas perawatan kesehatan, dan sekolah semakin menggunakan metode eksperimental untuk berbagai tujuan terapan. Sebagai contoh, angkatan darat AS menerapkan tes kecerdasan selama Perang Dunia I Transue menggabungkan logika eksperimen dengan metode penelitian survei dalam satu penelitian dan menguji teori ilmu sosial abstrak dengan menerapkannya pada persoalan kebijakan nyata publik. Karyanya memberikan kontribusi terhadap litelatur yang berkembang dan menunjukkan cara penekanan yang halus pada perbedaan ras di antara orang Amerika cenderung untuk menonjolkan perpecahan rasial berkaitan dengan berbagai persoalan publik (Neuman, 2017).

Menurut teori identitas sosial, kita secara otomatis mengkategorikan orang lain ke dalam in-group (kelompok-kelompok yang kita termasuk di dalamnya) dan out-group (kelompok-kelompok yang kita tidak termasuk). Kelompok-kelompok ini membentuk dasar dari berbagai batasan sosial dan perasaan mengenai jarak sosial atau kedekatan dengan orang lain. Kita juga memiliki banyak identitas. Suatu sub himpunan dari teori yang lebih luas, kategorisasi diri (self-categorization), mengatakan kita mengkategorisasi ulang orang lain sebagai anggota dalam in-group atau out-group berdasarkan identitas mana yang lebih aktif. Batas-batas sosial dan perasaan mengenai jarak sosial bergantung pada in-group yang paling menonjol. Kita merasa lebih dekat dengan anggota in-group dan lebih jauh dari orang-orang dalam outgroup yang menonjol. Priming adalah proses 
dengan sesuatu terjadi untuk mengaktifkan identitas tertentu. Setelah diaktifkan, identitas ini cenderung memiliki pengaruh yang lebih besar terhadap perilaku atau pola pikir berikutnya. Setelah diingatkan mengenai suatu identitas (yaitu, setelah mencapai puncak/ kematangannya), identitas mempengaruhi cara kita berpikir tentang diri sendiri dan oleh karenanya mempengaruhi perilaku kita (Neuman, 2017).

Dalam kebanyakan studi masa lalu mengenai teori identitas sosial, peneliti menggunakan percobaan labolatorium dengan sampel kemudahan (convenience) mahasiswa dalam jumlah sedikit dan menguji efek dari identitas yang tercipta secara temporer dan artifisial terhadap persoalan buatan/ rancangan. Transue pada tahun 2007 berusaha memperoleh validitas eksternal yang lebih besar. Untuk medapatkannya, ia menggunakan sampel acak orang dewasa dalam jumlah besar, identitas sosial yang sebenarnya, dan masalah kebijakan publik yang nyata. Penelitiannya menggunakan survei telepon sampel acak dari 405 warga AS berkulit putih di daerah metropolitan minneapolis dalam musim panas 1998 yang mengandalkan random-digit dialing. Transue mempertimbangkan dua identitas yang sebenarnya, ras dan bangsa. Ia melandasi penelitiannya pada studi sebelumnya yang menunjukkan prasangka ras warga kulit putih yang telah mencapai puncak atau mengingatkan ras mereka agar lebih berpikir dengan cara rasis ketika mereka memberikan suaranya. Persoalan kebijakan nyata yang ia periksa adalah dukungan untuk membayar pajak yang ditujukan pada sekolah umum (Neuman, 2017).

\section{Pengertian Penelitian Eksperimen}

Penelitian eksperimental adalah salah satu penelitian yang paling kuat metodologi yang dapat digunakan para peneliti. Dari banyak jenis penelitian yang mungkin digunakan, eksperimen adalah cara terbaik untuk menetapkan sebab-akibat hubungan antar variabel. Namun percobaan tidak selalu mudah dilakukan (Fraenkel, Wallen, \& Hyun, 2014).

Penelitian eksperimental dibangun di atas prinsip-prinsip dari pendekatan positivis yang dilakukan Ilmuwan alam (misalnya, ahli kimia atau ahli biologi) dan peneliti terkait bidang terapan (misalnya, pertanian, teknik, dan obat) melakukan eksperimen. Kita juga bisa menggunakan eksperimen dalam pendidikan, peradilan pidana, jurnalisme, pemasaran, keperawatan, ilmu politik, psikologi, kerja sosial, dan sosiologi untuk memeriksa banyak sosial masalah dan teori (Neuman, 2017). Neuman (2017) juga mengatakan dalam bahasa masuk akal, eksperimen berarti mengubah satu hal dalam suatu situasi dan kemudian membandingkan hasilnya dengan hal yang ada tanpa modifikasi.

Pendapat lain tentang penelitian eksperimen dikemukakan oleh Sukardi (2016), menurutnya metode penelitian eksperimen merupakan metode penelitian yang paling produktif, karena jika penelitian 
tersebut dilakukan dengan baik dapat menjawab hipotesis yang utamanya berkaitan dengan hubungan sebab akibat. Disamping itu, penelitian eksperimen juga merupakan salah satu bentuk penelitian yang memerlukan syarat yang relatif lebih ketat jika dibandingkan dengan jenis penelitian lainnya. Hal ini karena sesuai dengan maksud para peneliti yang menginginkan adanya kepastian untuk memperoleh informasi tentang variabel mana yang menyebabkan sesuatu terjadi dan variabel yang memperoleh akibat dari terjadinya perubahan dalam suatu kondii eksperimen.

Lebih sederhana, Sugiyono mengatakan bahwa metode penelitian yang digunakan untuk mencari pengaruh perlakuan tertentu terhadap yang lain dalam kondisi yang terkendalikan. Menurutnya, dalam penelitian eksperimen ada perlakuan (treatment) sedangkan dalam penelitian naturalistik tidak ada perlakuan.

\section{Karakteristik Penelitian Eksperimen}

Dari semua metodologi penelitian yang dijelaskan, penelitian eksperimental memiliki dalam dua hal yang sangat penting: yaitu satusatunya jenis penelitian yang langsung mencoba untuk mempengaruhi suatu variabel tertentu, dan ketika diterapkan dengan benar, penelitian bisa dibilang sebagai jenis pengujian hipotesis terbaik tentang untuk mengetahui hubungan sebab-akibat.

Di sebuah eksperimen belajar, peneliti melihat efek dari setidaknya satu variabel independen pada satu atau lebih banyak variabel dependen. Variabel independen dalam penelitian eksperimen juga sering disebut sebagai eksperimen, atau treatment, variabel. Sedangkan variabel dependen, juga dikenal sebagai kriteria, atau hasil, variabel, mengacu pada hasil penelitian (Fraenkel et al., 2014; Neuman, 2017)

\section{Bentuk Desain Eksperimen}

Terdapat beberapa jenis desain penelitian eksperimen. Secara umum dibedakan menjadi 4.

Rancangan Pra- Eksperimen (Pre Experimental Designs)

Dikatakan Pre Experimental Designs, karena desain ini belum merupakan eksperimen sungguh-sungguh. Hal ini dikarenakan masih terdapatnya variabel luar yang ikut berpengaruh terhadap terbentuknya variabel dependen (Sugiyono, 2017). Desain ini merupakan rencana percobaan yang tidak memiliki penugasan acak atau menggunkan jalan pintas dan jauh lebih lemah dibandingkan rancangan eksperimental klasik; diganti dalam situasi saat peneliti tidak bisa menggunakan seluruh fitur rancangan eksperimen klasik tetapi rancangannya memiliki validitas internal yang lebih lemah (Neuman, 2017).

Di dalam Pre Experimental Designs dibagi lagi menjadi tiga jenis yaitu One-shot case study, One-Group Pretest-Posstest design, dan Intact-Group Comparison.

True Experimental Design

Dikatakan true experimental 
(eksperimen yang betul-betul), karena dalam desain ini, peneliti dapat mengontrol semua variabel luar yang mempengaruhi jalannya eksperimen. Dengan demikian validitas internal (kualitas pelaksanaan) dapat menjadi tinggi (Sugiyono, 2017).

Ciri utama dari true experimental adalah bahwa, sampel yang digunakan untuk eksperimen maupun sebagai kelompok kontrol diambil secara random dari populasi tertentu. Jadi cirinya adalah adanya kelompok kontrol dan sampel dipilih secara random. Pada true experimental terbagi lagi menjadi dua jenis yaitu Posttest Only Control Design and Pretest Group Design (Sugiyono, 2017).

\section{Factorial Design}

Desain faktorial merupakan modifikasi dari design true experimental, yaitu dengan memperhatikan kemungkinan adanya variabel moderator yang mempengaruhi pelakuan (variabel independen) terhadap hasil (variabel dependen) (Sugiyono, 2017).

Quasi Experimental Design

Bentuk desain eksperimen ini merupakan pengembangan dari true experimental design, yang sulit dilaksanakan. Desain ini mempunyai kelompok kontrol, tetapi tidak dapat sepenuhnya untuk mengontrol variabel-variabel luar yang mempengaruhi pelaksanaan eksperimen (Sugiyono, 2017).

Walaupun demikian desain ini lebih baik dari pre-experimental design. Quasiexperimental design, digunakan karena pada kenyataannya sulit mendapatkan kelompok kontrol yang digunakan untuk penelitian (Sugiyono, 2017).

Dalam suatu kegiatan administrasi atau manajemen, sering tidak mungkin menggunakan sebagian para karyawannya untuk eksperimen dan sebagian tidak. Sebagian menggunakan prosedur kerja baru yang lain tidak (Sugiyono, 2017).

Oleh karena itu, untuk mengatasi kesulitan dalam menentukan kelompok kontrol dalam penelitian, maka dikembangkan desain Quasi Experimental (Sugiyono, 2017).

\section{MATERI DAN METODE}

\section{Kerangka Pemecahan Masalah.}

Dalam artikel ini dapat digambarkan kerangka permasalahan yang dihadapi oleh guru saat ini terdapat pada Gambar 1.

Dengan diberikannya pelatihan dan pendampingan, diharapkan guru dapat memiliki kemampuan dan pengetahuan dalam melakukan penelitian eksperimen yang ujungnya akan berdampak pada kenaikan pangkat guru dan akreditasi sekolah.

\section{Khalayak sasaran}

Sasaran yang menjadi peserta pelatihan ini adalah Guru di SMK IKIP Gedangan Sidoarjo dan Guru SMK IKIP Surabaya. Jumlah peserta yang diundang adalah 25 orang. Sedangkan target yang diharapkan dalam kegiatan pelatihan penulisan proposal penelitian eksperimen adalah (1) peserta memiliki pengetahuan tentang Penelitian Eksperimen, (2) peserta dapat mengisi kerangka proposal penelitian eksperimen (3) 
Hasil Observasi Peserta Pelatihan.

\section{Tahapan Pelaksanaan Pelatihan}

Observasi Awal

Kegiatan pelaksanaan observasi awal dilakukan dengan tujuan menggali kondisi peserta pelatihan seperti karakteristik peserta, tempat pelatihan serta waktu dilaksanakannya pelatihan telah sesuai dengan kesepakatan antara tim PKM dengan Mitra. Jika sudah terjadi kesepakatan antara tim PKM dengan mitra, maka kegiatan PKM siap dilaksanakan.

\section{Penyusunan Soal Pretest \& Postest}

Penysunan soal pretest dan posttest dilakukan dengan tujuan agar ketika pelaksanaan pelatihan tiba, instrument yang akan digunakan dalam pelatihan sudah siap. Diberikannya pre- test dan posttest adalah untuk mengukur keefektifan pelatihan yang telah dilakukan.

\section{Pelaksanaan Pelatihan}

Pada tahap pelaksanaan pelatihan awalnya diberikan pretest sebelum peserta mendapatkan materi pelatihan. Tujuannya adalah untuk mengetahui kemampuan awal peserta. Kemudian dilanjutkan dengan pelaksanaan pelatihan dengan rincian Tabel 1. Pelaksanaan Pendampingan

Pelaksanaan pendampingan dilakukan secara off class dan dilakukan oleh semua tim PKM. Hal ini dikarenakan keterbatasan waktu pelatihan. Pendampingan dilakukan hingga proposal yang disusun peserta pelatihan telah terselesaikan. Pendampingan yang dilakukan juga bertujuan untuk memotivasi peserta

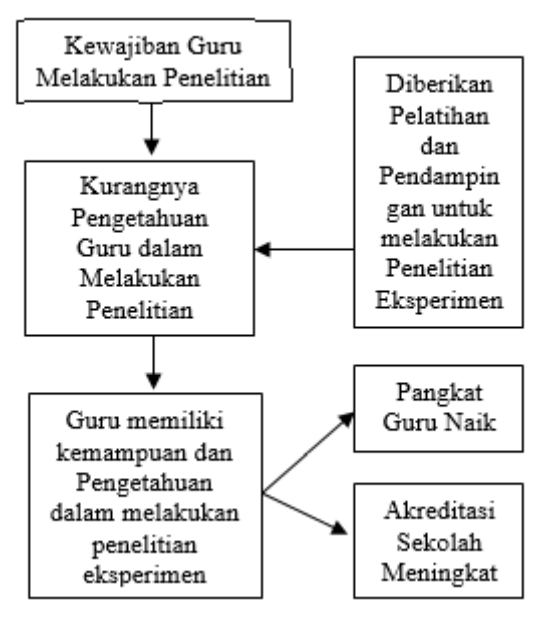

Gambar 1

Kerangka Pemecahan Masalah 
supaya kendala yang terjadi selama proses penulisan proposal dapat terselesaikan.

Telaah Proposal Penelitian Eksperimen yang disusun peserta

Telaah proposal penelitian eksperimen yang disusun oleh peserta dilakukan dengan tujuan memperbaiki proposal yang telah disusun. Telaah dilakukan secara on class. Semua tim PKM ikut memberikan masukan kepada proposal yang telah disusun dengan tujuan perbaikan proposal.

\section{Metode Pendekatan}

Metode Pendekatan yang digunakan dalam PKM ini disesuaikan berdasarkan tahapan pelaksanaan pelatihan sebagai berikut:

Observasi Awal

Metode yang digunakan dalam pelaksanaan observasi awal adalah wawancara. Wa- wancara dilakukan kepada perwakilan dari guru dari SMK IKIP Gedangan dan SMK IKIP Surabaya.

Penyusunan Soal Pretest \& Postest

Penyusunan soal pretest dan posttest dilakukan dengan metode diskusi antar sesama Tim PKM. Tentu saja soal tersebut disusun dan disesuaikan dengan materi penelitian eksperimen.

Pelaksanaan Pelatihan

Pelaksanaan pelatihan dilakukan dengan metode ceramah bervariasi, praktek, diskusi dan tanya jawab. Sebelum materi disampaikan penyahi, peserta diberikan pretest. Kemudian, materi disampaikan oleh penyaji secara berurutan mulai dari hakekat hingga penyusunan kerangka proposal penelitian eksperimen. Di akhir pelaksanaan pelatihan peserta diberikan post test.

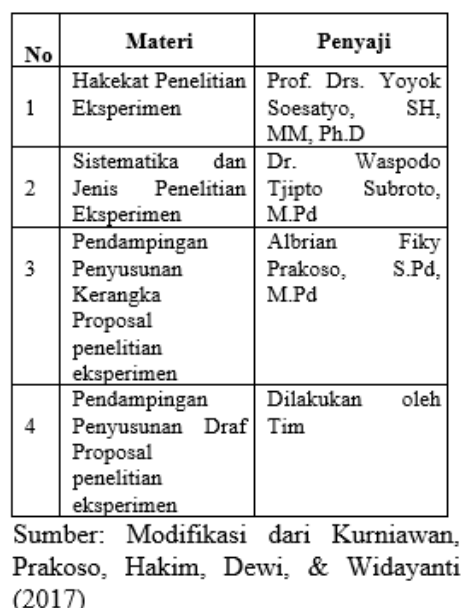

Tabel 1

Rincian Materi Pelatihan 
Pelaksanaan Pendampingan

Pelaksanaan pendampingan yang dilakukan secara off class dapat diikuti peserta via email dan sosial media. Segala kesulitan yang dialami peserta didiskusikan dengan tim PKM hingga terselesaikannya proposal penelitian.

Telaah Proposal Penelitian Eksperimen yang disusun peserta.

Telaah proposal dilakukan dengan cara diseminarkan oleh peserta on class. Metode yang diberikan adalah diskusi antara tim PKM dengan peserta pelatihan yang melakukan presentasi. Perbaikan proposal harus dilakukan oleh peserta pelatihan hingga proposal menjadi lebih baik lagi.

\section{HASIL DAN PEMBAHASAN}

\section{Deskripsi Hasil}

Kegiatan pengabdian kepada masyarakat ini dilaksanakan di Fakultas Ekonomi Universitas Negeri Surabaya yang beralamat di J1. Ketintang Kampus Unesa 60231 Surabaya. Kegiatan pengabdian kepada masyarakat ini dilakukan dalam bentuk pelatihan dengan metode ceramah dan praktek menyusun kerangka proposal penelitian eksperimen dan dilanjutkan dengan pendampingan penyusunan proposal penelitian eksperimen sebagai upaya untuk meningkatkan kemampuan guru SMK IKIP Gedangan dan SMK IKIP Surabaya dalam menyusun proposal penelitian eksperimen dengan baik. Kegiatan ini ditujukan kepada guru SMK IKIP Gedangan dan SMK IKIP Surabaya sejumlah 25 orang.

\section{Pemecahan Masalah}

Kegiatan Persiapan Pelatihan

Sebelum melaksanakan kegiatan pelatihan, dilakukan terlebih dahulu komunikasi dengan perwakilan guru SMK IKIP Gedangan dan SMK IKIP Surabaya. Komunikasi tersebut dilakukan untuk memperoleh jenis materi pelatihan yang dibutuhkan guru disana. Komunikasi tersebut mendapatkan hasil yaitu pelatihan yang dibutuhkan guru antara lain pelatihan penulisan penelitian, penulisan artikel ilmiah, dan Evaluasi Pembelajaran.

Tim PKM kemudian melakukan koordinasi dengan tim PKM lainnya untuk menyusun perencanaan pelaksanaan PKM. Koordinasi tersebut menghasilkan pembagian materi pada setiap anggota tim PKM.

Langkah berikutnya Tim PKM melakukan koordinasi dengan Ketua Yayasan dari SMK IKIP Gedangan dan SMK IKIP Surabaya untuk bekerja sama dalam pelasanaan PKM. Dengan demikian peserta ditugaskan oleh Yayasan sehingga tim PKM hanya tinggal mempersiapkan materi pelatihan.

Materi untuk pelatihan penulisan proposal eksperimen didapatkan dari berbagai dokumen pemateri melalui berbagai kegiatan sebagai reviewer soal evaluasi baik di jenjang SMP maupun SMA dan pelatihan yang diikuti oleh pemateri.

Pelaksanaan pelatihan 
Pelaksanaan pelatihan bertempat di $\mathrm{Ru}-$ ang Pertemuan Gedung G5 Fakultas Ekonomi Universitas Negeri Surabaya. Peserta yang mengikuti pelatihan ini adalah SMK IKIP Gedangan dan SMK IKIP Surabaya yang dipertemukan dalam satu ruang.

Kegiatan pengabdian kepada masyarakat disampaikan kepada SMK IKIP Gedangan dan SMK IKIP Surabaya dan memperoleh respon positif. Selanjutnya kegiatan dikoordinasikan oleh Tim Pelaksana yaitu dengan cara menyampaikan informasi pelaksanaan Pelatihan penulisan proposal penelitian eksperimen. Pelaksanaan pelatihan dilakukan selama dua hari yaitu pada tanggal 11 Agustus 2018 kemudian malam harinya dilanjutkan pendampingan secara daring dan keesokan harinya dilakukan telaah.

Materi yang pertama yaitu Hakekat Penelitian Eksperimen disampaikan oleh bapak Prof. Drs. Yoyok Soesatyo, SH, MM, Ph.D. Materi yang kedua yaitu Sistematika dan Jenis Penelitian Eksperimen yang disampaikan oleh Bapak Dr. Waspodo Tjipto Subroto, M.Pd. Setelah memahami teori, materi dilanjutkan dengan Praktek menyusun kerangka proposal penelitian eksperimen yang dipandu oleh Bapak Albrian Fiky Prakoso, S.Pd, M.Pd. Pelatihan hari pertama ditutup dengan sesi Tanya Jawab dan peserta diminta untuk menyusun proposal penelitian eksperimen dari kerangka yang telah dibuat pada hari pertama. Tim PKM melakukan pendampingan secara daring dan kemudian keesokan harinya peserta dan tim PKM bertemu kembali untuk melakukan telaah proposal yang telah disusun peserta.

Acara hari kedua yaitu tim PKM melakukan telaah proposal penelitian eksperimen yang telah disusun oleh peserta. Sebelum melakukan telaah peserta diminta untuk mengumpulkan draf proposal penelitian eksperimen yang telah mereka susun. Tim PKM meminta perwakilan dari peserta yang memiliki proposal penelitian eksperimen yang sesuai dengan kriteria Tim PKM untuk melakukan presentasi. Kegiatan berikutnya dilanjutkan dengan para pemateri mereview dan memberikan masukan tentang telaah analisis butir soal yang telah dilakukan oleh peserta dan juga dilakukan diskusi antara pemateri dengan peserta.

Pelaksanaan PKM yang telah dilakukan dapat dibuktikan dengan dokumentasi pada Gambar 2.

Respon Peserta Pelatihan

Berdasarkan hasil komunikasi dengan Guru SMK IKIP Gedangan dan SMK IKIP Surabaya, maka didapatkan hasil kuesioner persepsi mereka tentang pelatihan penulisan proposal eksperimen. Respon tersebut dibuat dalam bentuk grafik pada Gambar 3.

Sebanyak 35,6 \% peserta merasa sangat puas, $57,2 \%$ peserta merasa puas, dan $7,2 \%$ peserta merasa cukup dengan aspek akademik yang diberikan oleh tim PKM. Kemudian tidak ada peserta yang merasa tidak puas dan sangat tidak puas. Nilai cukup terbanyak berada pada indikator kesempatan dalam mendapatkan umpan balik. Kesempatan ini dirasa kurang oleh peserta. 
Hal ini dikarenakan terlalu banyaknya peserta yang menginginkan umpan balik sehingga kesempatan untuk mendapatkannya tidak merata untuk setiap peserta.

Aspek berikutnya adalah dari sisi narasumber pelatihan yang ditampilkan pada grafik pada Gambar 4.

Pada dasarnya sebagian besar peserta merasa sangat sesuai dan sesuai tentang narasumber yang menyampaikan materi pada pelatihan ini. Namun disisi lain sebanyak $17,8 \%$ peserta merasa cukup sesuai. Nilai cukup sesuai ini didominasi oleh Efisiensi dalam menjelaskan konsep materi latihan yang diberikan pemateri. Hal ini dirasa kurang oleh peserta karena narasumber ketika menjawab pertanyaan dari peserta tentang jenis penelitian lain. Pertanyaan tersebut berkaitan dengan perbedaan antara penelitian eksperimen dengan jenis penelitian lain seperti penelitian pengembangan. Ketika menjawab, narasumber terbawa situasi untuk lebih banyak menjelaskan penelitian pengembangan dan akhirnya berdampak pada berkurangnya penjelasan tentang penelitian eksperimen.

Aspek yang terakhir yaitu tentang pengelolaan/ pelaksanaan. Respon pesertanya terdapat pada Gambar 5.

Aspek pengelolaan/ pelaksanaan berhubungan erat dengan tempat dan fasilitas dalam pelaksanaan pelatihan. Hasil hasil analisis kuesioner yang telah disebarkan, didapatkan sebagian peserta merasa sangat puas dan puas terhadap pengelolaan/ pelaksanaan pelatihan. Hanya saja terdapat $5,4 \%$ peserta merasa cukup puas. Hal ini

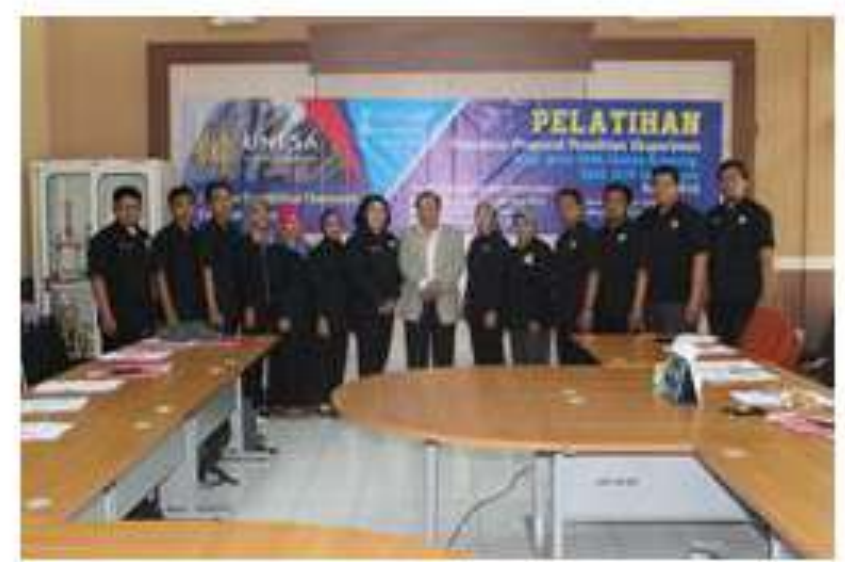

Gambar 2

Pelaksanaan PKM 
dikarenakan fasilitas yang diberikan seperti tempat dan konsumsi sederhana. Disisi lain, Tim PKM mengedepankan kedisiplinan waktu pelaksanaan pelatihan, sehingga setelah coffe break maupun Ishoma terdapat beberapa peserta yang ketinggalan untuk mengikuti materi dan Tim PKM tidak bisa mengulangi kembali materi yang disampaikan karena berpedoman pada susunan acara dan keterbatasan waktu.

\section{Keefektifan Pelatihan}

Untuk melihat keefektifan pelatihan yang diberikan oleh Tim PKM, maka diberikan pre-test dan post-test. Soal tersebut terdiri dari 10 Item pertanyaan yang diberikan pada saat sebelum dan sesudah pelatihan diberikan. Waktu yang disediakan Tim PKM adalah 10 menit. Berikut adalah perbandingan Hasil nilai pre-test dan post-test.

Secara umum kemampuan peserta dalam memahami proposal penelitian eksperimen sudah baik. Terbukti bahwa $44 \%$ peserta memiliki nilai pre-test diatas 60 . Tetapi karena pemahaman peserta tentang penelitian eksperimen yang hampir sama dengan penelitian tindakan kelas membuat mereka menjadi ragu untuk menjawabnya. Setelah diberikan pelatihan dan diberikan paparan materi tentang penelitian eksperimen dan perbedaannya dengan penelitian lain termasuk penelitian tindakan kelas, peserta memiliki kenaikan nilai pada post-test. Kenaikannya cukup signifikan yang semula $44 \%$ menjadi $72 \%$. Dengan dimikian pelatihan yang diberikan oleh tim PKM dapat dikatakan cukup efektif karena
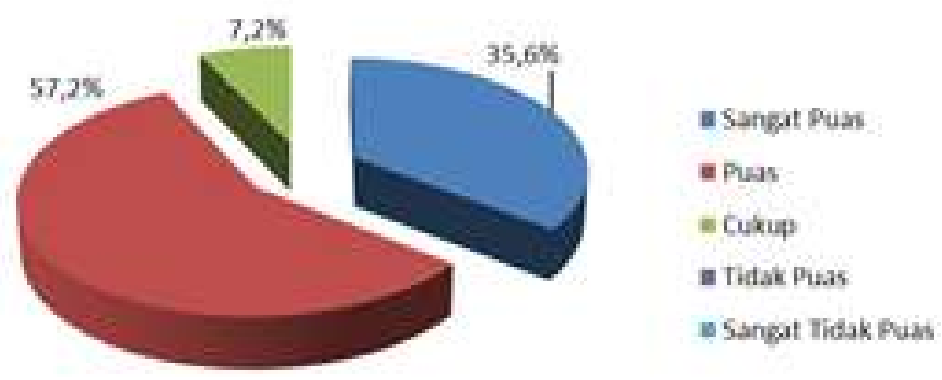

Gambar 3

Respon Indikator Akademik 
dapat meningkatkan pengetahuan peserta yang dibuktikan dengan kenaikan nilai test sebesar $28 \%$.

\section{Hasil Telaah Proposal}

Hasil telaah proposal penelitian eksperimen yang disusun peserta ditampilkan pada tabel 2.

Berdasarkan tabel diatas dapat diketahui bahwa dari 25 peserta yang mengikuti pelatihan, hanya 9 peserta yang mengumpulkan draf proposal sesuai dengan permintaan Tim PKM. Dari Ke 9 draf proposal tersebut pun tidak semuanya memenuhi persyaratan yang ditentukan oleh Tim PKM. Dari 9 draf proposal yang telah ditelaah tim PKM hanya 1 draf proposal yang mendekati kriteria yang diinginkan oleh Tim PKM baik dari Bab 1, Bab 2 , bab 3 , relevansi teori maupun penelitian terdahulu.

\section{Hasil Observasi}

Hasil observasi tersebut dapat dilihat pada tabel 3 .

Berdasarkan hasil observasi sebagian besar peserta yang mengikuti pelatihan sangatlah antusias. Terbukti hanya pada semua tahap kegiatan tidak lebih dari 3 peserta yang tidak mengikutinya.

\section{Pembahasan}

Seluruh peserta pelatihan penulisan proposal penelitian eksperiman pada dasarnya antusias dalam mendengarkan penjelasan materi yang diberikan oleh Narasumber. Disisi lain, sebagian besar peserta juga mengikuti keseluruhan rangkaian acara pelatihan walaupun terdapat satu peserta yang terlambat hadir di awal pelatihan dan satu lagi peserta yang terlambar hadir setelah ishoma dan tertinggal

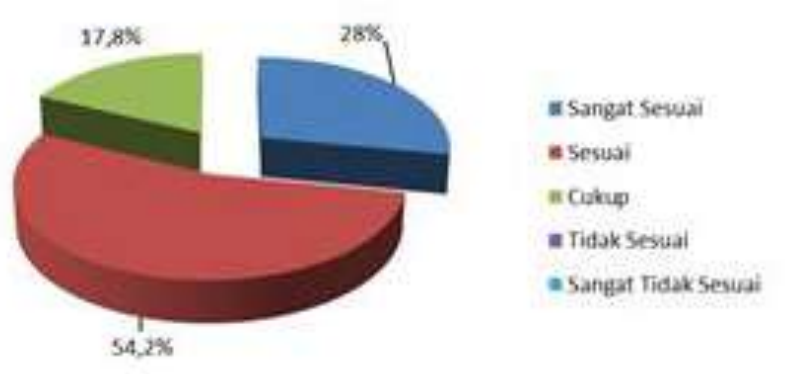

Gambar 4

Respon Indikator Narasumber 
ketika materi praktek membuat kerangka proposal. Kemudian pada saat praktek penyusunan kerangka proposal penelitian eksperimen, hanya 1 peserta yang tidak bisa menyelesaikannya sesuai dengan waktu yang ditentukan oleh panitia. Hal ini dikarenakan jari peserta sebelum pelatihan sudah mengalami sakit/ cidera sehingga kesulitan dalam menulis dengan cepat.

Pada sesi tanya jawab, terdapat peserta yang masih memerlukan pemahaman tentang bagaimana cara menentukan kelas eksperimen dan kelas kontrol, sehingga tim PKM memberikan penjelasan kembali. Kemudian masih terdapat pula peserta yang masih jumbo atau belum sepenuhnya bisa membedakan antara penelitian eksperimen dan PTK. Sehingga tim PKM memberikan sekilas penjelasan tentang Perbedaan kedua jenis penelitian tersebut dan untuk memahami PTK secara singkat maka peserta diminta mendownload serta membaca cepat contoh artikel PTK yang dilakukan oleh Prakoso (2013).

Disisi lain saat tim PKM mewawancarai peserta, terdapat pengakuan yang mengatakan mereka ingin melakukan penelitian eksperimen ketika mereka mengajar di sekolah. Tetapi disisi lain terdapat juga peserta yang masih belum memahami betul bagaimana tahapan peneltian eksperimen mulai dari permasalahan, pemilihan kelas kontrol dan kelas eksperimen hingga analisis data. Ke depan pendampingan akan dilanjutkan hingga pembuatan laporan penelitian eksperimen mengingat peserta sangat antusias dan penasaran dengan cara
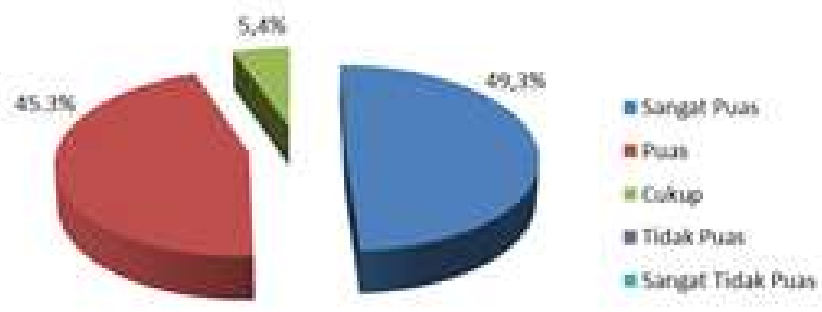

Gambar 5

Respon Indikator Pengelolaan/ Pelaksanaan 
menganalisis data pada penelitian eksperimen.

Untuk melakukan evaluasi pelaksanaan pelatihan penulisan proposal penelitian eksperimen, maka hasil analisis kuesioner tentang respon peserta yang telah disebarkan oleh tim PKM akan ditindaklanjuti. Tindak lanjut tersebut dilakukan bersama semua Tim PKM yang dilakukan pada Guru SMK IKIP Gedangan dan SMK IKIP Surabaya agar kedepan lebih memperhatikan peserta yang menginginkan umpan balik. Perbaikan ke depan Tim PKM menambahkan waktu dan memberikan kesempatan yang merata bagi peserta yang belum puas dalam mendapatkan umpan balik dari Tim PKM.

Kemudian upaya perbaikan yang perlu diberikan oleh pemateri adalah lebih mengefisiensi dalam menjelaskan konsep materi latihan. Materi yang dipaparkan hendaknya lebih fokus pada penelitian eksperimen, dan moderator harus memberikan masukan kepada pemateri apabila terjadi pembahasan diluar materi pelatihan. Terakhir layanan umum panitia walaupun sudah cukup bagus namun masih perlu ditingkatkan yakni dengan menambahkan waktu pada kegiatan coffe break dan ishoma agar peserta tidak ketinggalan materi ketika mereka melaksanakan coffe break dan ishoma.

Dari sisi draf proposal penelitian eksperimen yang telah dibuat oleh peserta terdapat beberapa kekurangan. Mengingat peserta berasal dari guru yang mana bidang studinya berbeda beda.

Dalam menyusun latar belakang, peserta masih belum memahami benar tentang

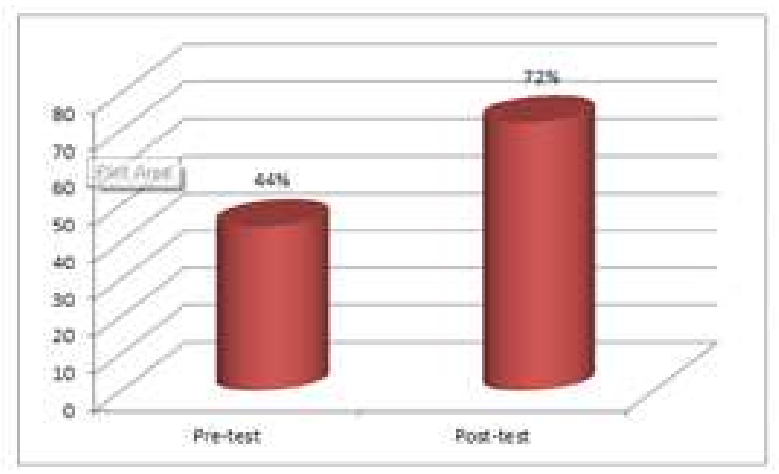

Gambar 6

Respon Indikator Pengelolaan/ Pelaksanaan 
permasalahan apa yang bisa diatasi dengan penelitian eksperimen. Sebagian besar peserta mengungkapkan permasalahan pribadi yang dialami siswa sehingga kurang sesuai jika dibawa ke dalam penelitian eksperimen. Kemudian pemateri memberikan contoh permasalahan yang sesuai dengan permasalahan yang bisa diatasi dengan penelitian eksperimen seperti minat belajar peserta didik yang rendah, nilai atau hasil belajar yang rendah dan aturan yang mengharuskan guru untuk menerapkan suatu model pembelajaran tertentu yang sesuai dengan kurikulum yang berlaku.

Dari segi judul, banyak peserta yang kebingungan membuat judul yang identik dengan ciri khas penelitian eksperimen dan keluar dari ciri khas judul PTK. Kesulitan memilih model pembelajaran Ditambah lagi terdapat peserta yang berasal dari program studi bimbingan konseling yang tentunya pasti berbeda jika dibandingkan dengan program studi pada umumnya.

Kesulitan berlanjut ketika peserta diminta untuk membuat rumusan masalah. Perumusan masalah yang dibuat peserta belum menerminkan rumusan masalah seperti yang ada pada penelitian eksperimen pada umumnya.

Penulisan tentang kajian pustaka juga menjadi permasalahan tersendiri. Banyak dari peserta belum memahami teori apa saja yang seharusnya dimasukkan di bab kajian pustaka. Pemateri memberikan arahan tentang cara mudah memberikan hal apa saja yang dimasukkan di kajian pustaka seperti hasil belajar, model pembelajaran dan penelitian

\begin{tabular}{|c|c|c|c|c|c|}
\hline \multirow{2}{*}{$\begin{array}{c}\text { No. } \\
\text { Urut } \\
\text { Peserta }\end{array}$} & \multicolumn{3}{|c|}{$\begin{array}{l}\text { Kesesuaian } \\
\text { Sistematika }\end{array}$} & \multicolumn{2}{|c|}{ Relevansi } \\
\hline & $\begin{array}{c}\text { Bab } \\
1\end{array}$ & $\begin{array}{c}\text { Bab } \\
2\end{array}$ & $\begin{array}{c}\mathrm{Bab} \\
3\end{array}$ & Judul & $\begin{array}{c}\text { Teori \& } \\
\text { Penelitian } \\
\text { Terdahulu }\end{array}$ \\
\hline 1 & $\mathrm{~V}$ & - & $\mathrm{v}$ & $\mathrm{V}$ & - \\
\hline 2 & $\mathrm{~V}$ & $\mathrm{v}$ & $\mathrm{v}$ & $\mathrm{V}$ & $\mathrm{v}$ \\
\hline 3 & $\mathrm{~V}$ & - & - & - & - \\
\hline 4 & $\mathrm{~V}$ & $\mathrm{~V}$ & - & - & $\mathrm{V}$ \\
\hline 5 & $\mathrm{~V}$ & $\mathrm{v}$ & - & $\mathrm{V}$ & - \\
\hline 6 & $\mathrm{v}$ & - & - & - & - \\
\hline 7 & $\mathrm{~V}$ & - & - & - & - \\
\hline 8 & $\mathrm{~V}$ & $\mathrm{v}$ & - & $\mathrm{V}$ & - \\
\hline 9 & $\mathrm{~V}$ & - & - & $\mathrm{v}$ & - \\
\hline
\end{tabular}

Tabel 2

Hasil Telaah Proposal 
terdahulu.

Terdapat juga peserta yang menanyakan apakah ada ketentuan tentang berapa tahun maksimal buku yang hendak dirujuk dan bagaimana jika mereka merujuk melalui internet. Pemateri menjawab dengan tegas bahwa merujuk teori dari intenet seperti blogspot harus dihindari, selain karena tidak adanya review juga memiliki resiko plagiasi yang tinggi.

Pemateri juga memberikan pengetahuan tentang apa itu plagiasi da bagaimana cara mengatasinya. Peserta juga diberikan contoh pendeteksian plagiasi melalui salah satu software anti plagiasi yaitu Turnitin.
Banyak peserta yang memiliki persepsi bahwa dengan menulis teori dari sebuah buku bukan termasuk plagiasi, akan tetapi jika buku tersebut terlebih dahulu dirujuk oleh orang lain maka kita dianggap melakukan plagiat pada orang yang pertama kali merujuk buku tersebut. Kemudian pemateri memberikan sedikit tips untuk mengatasi plagiasi yaitu dengan cara melakukan parafrase.

Timbul pertanyaan lagi bagaimana cara mensitasi buku yang telah mereka miliki. Banyak hal yang didiskusikan terutama ketika pemateri juga memperkenalkan software manajemen referensi yaitu mendeley.

\begin{tabular}{|l|l|c|c|}
\hline No. & \multicolumn{1}{|c|}{ Aspek } & $\begin{array}{c}\text { Jumlah } \\
\text { Peserta }\end{array}$ & $\begin{array}{c}\text { Persentase } \\
(\%)\end{array}$ \\
\hline 1. & $\begin{array}{l}\text { Antusias dalam } \\
\text { mendengarkan } \\
\text { penjelasan } \\
\text { materi }\end{array}$ & 25 & 100 \\
\hline 2. & $\begin{array}{l}\text { Mengikuti } \\
\text { Pelatihan } \\
\text { Penulisan }\end{array}$ & 23 & 92 \\
$\begin{array}{l}\text { Proposal } \\
\text { Penelitian } \\
\text { Eksperimen } \\
\text { dari awal } \\
\text { hingga akhir } \\
\text { pelatihan }\end{array}$ & & \\
\hline 3. & $\begin{array}{l}\text { Mampu } \\
\text { Menyusun } \\
\text { kerangka } \\
\text { Proposal } \\
\text { Penelitian } \\
\text { Eksperimen } \\
\text { sesuai dengan } \\
\text { waltu yang } \\
\text { tersedia }\end{array}$ & 24 & 96 \\
\hline 4. & $\begin{array}{l}\text { Minat } \\
\text { Melakukan } \\
\text { penelitian } \\
\text { eksperimen } \\
\text { ketika di } \\
\text { sekolah }\end{array}$ & & \\
\hline
\end{tabular}

Tabel 6

Hasil Observasi Pelatihan Penulisan Proposal Eksperimen 
Pemateri juga memberikan pengertian tentang kutipan langsung dan kutipan tak langsung.

Kesulitan peserta berikutnya adalah mencari artikel yang telah diterbitkan di jurnal nasional maupun internasional. Banyak dari peserta beranggapan bahwa lebih mudah mencari skripsi yang diunggah secara online. Hal ini tidak diperbolehkan oleh pemateri dan menyarankannya untuk merujuk jurnal. Cara mengunduh jurnal yang terakreditasi juga diajarkan terutama yang terindeks di Science and Technology Index (Sinta) yang dimiliki oleh Kemristekdikti. Peserta juga dijelaskan tentang peringkat akreditasi jurnal nasional mulai dari sinta 1 hingga 6 .

Cara memperoleh jurnal internasional juga dicontohkan oleh pemateri. Alamat website jurnal internasional yang disarankan adalah www.sciencedirect.com

dan

www.emeraldinsight.com. Peserta juga sudah diberikan informasi agar ketika mengunduh artikel untuk memilih artikel yang free access atau open access.

Dalam menyusun bab II akhir terdapat hipotesis penelitian. Banyak peserta yang menganggap bahwa hipotesis hanya ada satu padahal terdapat dua hipotesis yaitu hipotesis penelitian dan hipotesis statistik. Sehingga pemateri kembali memberikan penjelasan tentang perbedaan antara hipotesis penelitian dan hipotesis statistik hingga semua peserta memahaminya.

Pemaparan materi beikutnya yaitu tentang bab III Metode penelitian. Pada materi di bab ini menjadi perbincangan yang sangat dinantikan oleh peserta. Hal ini dikarenakan banyak peserta mengeluh tidak mengerti tentang apa saja yang harus mereka lakukan dalam penelitian mereka. Pada bab ini pula peserta diberikan materi tentang hipotesis statistik dan cara pengambilan keputusannya.

Pada pemaparan di metode penelitian juga dijelaskan tentang pengujian yang diperlukan untuk penelitian eksperimen yaitu Uji beda. Dalam penjelasan tentang uji beda ini peserta diberikan pengetahuan tentang fungsi dari uji beda yang dilakukan pada pretest dan post-test.

Uji beda yang dijelaskan pemateri juga termasuk uji rata-rata kelompok terkait dan juga uji rata-ata kelompok bebas. Jika jenis penelitian eksperimen yang yang dilakukan oleh peserta adalah True Experiment maka uji yang disarankan menggunakan uji rata-rata kelompok terkait. Tetapi jika penelitian milik peserta termasuk dalam jenis penelitian Quasi Experiment maka uji yang disarankan adalah uji rata-rata dua kelompok bebas.

Setelah peserta menentukan jenis penelitian eksperimen apa yang mereka gunakan, langkah berikutnya adalah memahami cara menganalisis data peneltian eksperimen. Namun sebelum menganalisis dengan uji rata-rata, data milik peserta pelatihan harus memenuhi beberapa syarat. Syarat pengujian rata-rata pada data suatu penelitian harus lolos syarat dua uji yaitu normalitas dan uji homogenitas. Kedua uji prasyarat ini diperlukan guna mengetahui apakah analisis data untuk pengujian hipotesis 
dapat dilanjutkan atau tidak. Asumsi yang paling lazim pada uji parametrik adalah sampel acak yang berasal dari populasi yang berdistribusi normal, dataa bersifat homogen. Bila asumsi-asumsi ini tidak dipenuhi maka hasil yang didapat tidak akurat atau bias. Namun bila asumsi tidak dipenuhi maka uji nonparametrik menjadi alternatif (Nurhasanah, 2016).

Uji normalitas digunakan untuk mengetahui apakah distribusi sebuah data mengikuti atau mendekati distribusi normal (Nurhasanah, 2016). Peserta juga diberi pemahaman bahwa mereka harus melakukan uji normalitas terlebih dahulu sebelum data diolah.

Peserta kembali diberikan pemahaman tentang fungsi uji normalitas. Data yang diperoleh peserta atau data empiris yang didapatkan peserta dari lapangan sesuai dengan distribusi teoritis tertentu. Dengan kata lain, untuk mengetahui apakah data yang diperoleh berasal dari populasi yang berdistribusi normal (Nurhasanah, 2016).

Timbul pertanyaan dari peserta lagi tentang apa yang dimaksud data berdistribusi normal. Pemateri menjawab sesuai dengan sumber yang dirujuk dan menjelaskan bahwa data berdistrbusi normal artinya data mempunyai sebaran merata sehingga benarbenar mewakili populasi dari suatu penelitian. Jika data berdistribusi normal maka analisis statistik dapat memakai pendekatan parametrik, sedangkan jika data tidak berdistribusi normal maka analisis menggunakan pendekatan nonparametrik
(Nurhasanah, 2016).

Peserta juga diberikan penjelasan tentang teknik pengujian normalitas suatu distribusi data yang telah dikembangkan oleh para ahli. Beberapa teknik yang dapat peserta gunakan untuk menguji normalitas data adalah rumus Lilliefors, KolmogorovSmirnov, dan secara deskriptif melalui grafik Q-Q Plot, Box Plot, Histogram, Kurtosis, dan Skewness. Dari sekian banyak metode yang dapat digunakan untuk membuktikan normalitas sebuah data, ada satu metode yang paling sering digunakan dan peserta juga disarankan untuk menggunakan uji tersebut, yaitu dengan menggunakan rumus Kolmogorov-Smirnov. Peserta diberikan sedikit pemahaman tentang Uji KolmogorovSmirnov yang merupakan pengujian normalitas yang sering digunakan, terutam setelah berkembangnya program statistik yang beredar. Kelebihan uji ini juga dipaparkan oleh pemateri yaitu sederhana dan tidak menimbulkan perbedaan persepsi diantara satu pengamat dengan pengamat lain, yang sering terjadi pada uji normalitas dengan menggunkan grafik (Nurhasanah, 2016).

Seletah peserta diberi pemahaman tentang uji normalitas, langkah berikutnya pemateri memberikan sedikit pemahaman syarat uji rata-rata berikutnya yaitu harus lolos uji homogenitas. Uji homogenitas disampaikan ke peserta agar peserta memahami tujuan dari uji ini yaitu untuk memperliatkan bahwa dua atau lebih kelompok data (dalam hal ini nilai hasil 
belajar siswa) sampel berasal dari polulasi yang memiliki variansi yang sama. Homogenitas data yang didapatkan peserta pada penelitian eksperimen merupakan salah satu syarat yang direkomendasikan untuk diuji secara statistik, terutama bila menggunakan statistik uji parametrik, seperti uji $\mathrm{t}$ dan uji $\mathrm{F}$ (Nurhasanah, 2016). Uji yang disarankan pemateri untuk uji homogenitas adalah Levene test dimana uji ini sudah terdapat pada software SPSS.

Di akhir penjelasan pemateri sedikit mempraktekkan bagaimana cara menganalisis data dengan bantuan software SPSS. Respon peserta sangat positif dan sangat tertarik untuk melakukan praktek tersebut. Namun dikarenakan terbatasnya waktu maka pertemuan antara peserta dan tim PKM berikutnya adalah pelatihan praktek analsis data penelitian dengan software SPSS.

Setelah rangkaian acara materi selesai, peserta diberikan post-test. Perbedaan nilai peserta sebelum dan setelah mengikuti pelatihan tercermin dalam perbandingan nilai pre-test dan post-test. Kenaikan nilai signifikan terlihat pada nilai post-test. Hal ini berarti bahwa pelatihan yang diberikan oleh tim PKM cukup efektif. Sehingga dengan diberikannya pelatihan tentang penelitian eksperimen dapat meningkatkan pemahaman peserta tentang penelitian eksperimen (Khumaedi, Sunyoto, \& Nugroho, 2017).

\section{KESIMPULAN DAN SARAN}

Kesimpulan
Pelaksanaan PKM telah berjalan dengan baik, tetapi terdapat peserta yang merasa bahwa penjelasan konsep materi yang diberikan pemateri kurang efisien, kurangknya umpan balik yang diberikan pemateri, dan layanan panitia secara umum cukup puas. Pelatihan yang diberikan Tim PKM cukup efisien karena meningkatkan pengetahuan peserta tentang penelitian eksperimen dengan dibuktikan dengan perbandingan nilai pre-test dan post-test.

Keterbatasan waktu menjadi penyebab hanya sebagian peserta yang dapat menyelesaikan penyusunan draf proposal penelitian eksperimen dan tetapi terdapat peserta yang mampu menyusunnya sesuai dengan kriteria yang diinginkan Tim PKM. Terakhir, terdapat sebagian peserta yang masih belum bisa membedakan antara penelitian eksperimen dengan penelitian tindakan kelas. Implikasi pentingnya adalah guru di Indonesia membutuhkan pelatihan tentang penelitian agar jenjang karir mereka meningkat dan menjadi lebih profesional.

\section{Saran}

Untuk pelaksana PKM berikutnya diharapkan ketika melakukan praktek penyusunan kerangka proposal penelitian eksperimen hendaknya peserta diberikan kebebasan untuk menggunakan alat entah itu bolpoin dengan lembar kerja atau justru langsung mengerjakannya di laptop. Hal ini dilakukan agar peserta dapat dengan mudah mengubah kerangka proposal menjadi draf 
proposal penelitian. Kemudian juga karena animo peserta sangat tinggi untuk menganalisis data peneltian, maka disarankan juga untuk melaksanakan pelatihan lanjutan yaitu praktek menganalisis data hasil penelitian dengan bantuan software tertentu seperti software SPSS.

\section{DAFTAR PUSTAKA}

Arikunto, S., Suhardjono, \& Supardi. (2010). Penelitian Tindakan Kelas. Jakarta: Bumi Aksara.

Birokrasi, P. M. N. P. A. N. dan R. Jabatan Fungsional Guru dan Angka Kreditnya (2009).

Clark, A. (2009). An experiment in teaching invention. Education + Training, 51(7), $516-525$. https:// doi.org/10.1108/00400910910992727

Fraenkel, J. R., Wallen, N. E., \& Hyun, H. H. (2014). How to Design and Evaluate Research in Education (Ninth Edit). New York: McGraw-Hill.

Hietanen, L., \& Ruismäki, H. (2016). Awakening students' entrepreneurial selves: case music in basic education. Education + Training, 58(7/8), 832-848. https:// doi.org/10.1108/ET-02-2016-0047

Khumaedi, M., Sunyoto, S., \& Nugroho, A. (2017). Pelatihan Analisis Statistika Penelitian Eksperimen Tiga Perlakuan bagi Guru Guru SMK di Kota Semarang. Rekayasa, 14(2), 135-144. Retrieved from https://journal.unnes.ac.id/nju/ index.php/rekayasa/article/
view/8974\#.XAc4hSP-pAQ.mendeley

Kurniawan, R. Y., Prakoso, A. F., Hakim, L., Dewi, R. M., \& Widayanti, I. (2017). Pemberian Pelatihan Analisis Butir Soal Bagi Guru di Kabupaten Jombang; Efektif? Jurnal Pemberdayaan Masyarakat Madani (JPMM), 1(2), 179-193. https:// doi.org/10.21009/JPMM.001.2.03

Neuman, W. L. (2017). Metodologi Penelitian Sosial: Pendekatan Kualitatif dan Kuantitatif (7th ed.). Jakarta: PT Indeks. Nurhasanah, S. (2016). Praktikum Statistika 2 Untuk Ekonomi dan Bisnis. Jakarta: Salemba Empat.

Pahlevi, T., \& Prakoso, A. F. (2014). Pengaruh Pembelajaran Kooperatif Modified Think Pair Share (TPS) terhadap Minat Belajar, Keaktifan, dan Prestasi Belajar pada Mata Kuliah Pengantar Teori Ekonomi Mikro. In Seminar Nasional dan Call for Paper Pluralisme dalam Ekonomi dan Pendidikan (pp. 282-300). Malang: Jurusan Ekonomi Pembangunan Fakultas Ekonomi Universitas Negeri Malang.

Pillay, S., \& James, R. (2013). Gaming across cultures: experimenting with alternate pedagogies. Education + Training, 55(1), $7-22$. https:// doi.org/10.1108/00400911311294924

Prakoso, A. F. (2013). Penerapan Model CTL dengan Metode Problem Solving dalam Meningkatkan Hasil Belajar Kajian Kebutuhan Manusia Siswa SMK Muhammadiyah 5 Kalitidu. Jurnal Pendidi- 
kan Ekonomi, 6(1), 27-47.

Soejoto, A., Fitrayati, D., Ghofur, M. A., Sholikhah, N., \& Prakoso, A. F. (2017).

Pelatihan Penulisan Proposal Penelitian

Tindakan Kelas (PTK). Jurnal Abdi, 2(3),

51-59. https://doi.org/10.26740/

ja.v2n2.p51-59

Soesatyo, Y., Soejoto, A., Suratman, B., Subroto, W. T., Harti Harti, \& Hakim, L. (2018). Efektifitas Pemanfaatan Kemampuan Guru Ekonomi Kota Surabaya dalam Menulis Proposal Penelitian Tindakan Kelas. Jurnal Pemberdayaan Masyarakat Madani (JPMM), 2(1), 1-11. https:// doi.org/10.21009/JPMM.002.1.01

Sugiyono. (2017). Metode Penelitian Pendidikan (Pendidikan Kuantitatif, Kualitatif dan $R \& D)$. Bandung: Alfabeta.

Sukardi. (2016). Metodologi Penelitian Pendidikan (Kompetensi dan Prakteknya). Jakarta: Bumi Aksara.

West, J. T. (1962). Play-Making. Education + Training, 4(2), 14-15. https:// doi.org/10.1108/eb015087 